\title{
The Effect of Reward Toward Teacher's Motivation of Private Junior High School
}

\author{
Hardianto Hardianto ${ }^{1}$, Rugaiyah Rugaiyah ${ }^{2}$, Unifah Rosyidi ${ }^{3}$ \\ \{hardiantocally@gmail.com ${ }^{1}$, rugaiyah@unj.ac.id ${ }^{2}$, unifahrosyidi@unj.ac.id $\left.{ }^{3}\right\}$ \\ Universitas Negeri Jakarta, Indonesia ${ }^{123}$
}

\begin{abstract}
This study aims to see whether there is a direct influence reward on the motivation of private junior high school teachers in the Rokan Hulu Regency Riau province. Education will succeed if the teacher has high motivation in working. This study uses a quantitative method with a survey approach. Data collection is done by questionnaire. The results showed that there was a direct influence reward on the motivation of private junior high school teachers. This indicates that increasing teacher motivation can be done by increasing the reward they receive. The reward that is expected by the teacher is giving the opportunity to develop the competencies they have.
\end{abstract}

Keywords: Impact, Reward, Motivation, Teacher.

\section{Introduction}

To achieve educational goals, teachers who have high motivation in working are needed. Teachers who have motivation will be more enthusiastic in working. Teachers who have motivation are also not easy to give up in facing work problems.

The private junior high school teacher in Rokan Hulu seems to have no high motivation in work. Some indications indicate that teachers have not had high motivation. Among them there are still teachers who enter the class not on time. There are still teachers who do not design their own learning devices. The teacher was also less enthusiastic in participating in the activities held by the school

Reward is one of the factors that influences motivation. Reward do influence motivation and behavior [1]. Intrinsic and extrinsic rewards influence one's motivation [2]. Financial and non-financial rewards influenced motivation [3]. The reward had an effect on motivation [4].

Salary is one form of the rewards. The fact showed that the teacher still received the minimum salary in Rokan Hulu Regency. It can not to fullfil their daily need. The teacher get salary from school committee. It is currently ranges from Rp. 200 thousand to Rp. 300 thousand per month.It depends on the number of students at school [5]. In addition, the examination fees and supervision fees are also felt not to satisfy teacher' expectations.

This research is important to be done in order that the teacher's motivation in working becomes better and to achieve the educational goal. It is also realized that our country is the developing country that still need more efforts to achieve, build and develop. It is the increasing educational system.

In addition, many other factors influence the teachers' motivation. Based on the preliminary study, it is known that the reward is the dominant factor in the problem felt by the teacher of Private Junior High School in Rokan Hulu Regency. Therefore this research is 
limited by looking at reward as a factor that influences motivation. This research needs to be done so that teachers can be motivated in their work and finally be able to achieve educational goals optimally.

\section{Theory Framework}

\subsection{Motivation}

Motivation is a universal concept that must be aligned with the context and cultural background. What proves to be an extremely powerful motivator in one setting or country may be a miserable failure in another setting or nation [6]. Motivation is the forces within a person that affect the direction, intensity, and persistence of voluntary behavior [7]. Motivation is very important for a teacher. With motivation will emerge the power to do something.

Motivation referring to the forces either within or external to the person who arouse enthusiasm and persistence to pursue a certain course of action. Employee motivation affects productivity, and part of a manager's job is to channel motivation toward the accomplishment of organizational goals [8]. Motivation is divided into two, namely extrinsic and intrinsic motivation.

\subsection{Reward}

Reward is an operational concept for describing the positive value an individual ascribes to an object, behavioral act, or internal physical state [9]. Furthermore, total rewards typically encompass not only traditional, quantifiable elements like salary, variable pay and benefits, but also more intangible non-cash elements such as scope to achieve and exercise responsibility, career opportunities, learning and development, the intrinsic motivation provided by the work itself and the quality of working life provided by the organization [10].

Reward also divided into two, extrinsict reward and intrinsict reward. Intrinsict reward is a reward that comes from an internal realization that personal goals have been achieved. Extrinsic reward are reward from external sources, e.g. praise from supervisors, certificates [11]. Intrinsic rewards are the satisfactions a person receives in the process of performing a particular action. The completion of a complex task may bestow a pleasant feeling of accomplishment, or solving a problem that benefits others may fulfill a personal mission. Extrinsic rewards are given by another person, typically a manager, and include promotions, pay increases, and bonuses. They originate externally, as a result of pleasing others. Although extrinsic rewards are important, good managers strive to help people achieve intrinsic rewards as well [8].

\subsection{The impact of reward on motivation}

The way bonuses and rewards are categorized also affects peoples' motivation [12]. Intrinsic non-financial rewards related to responsibility, achievement and the work it self may have a longer-term and deeper impact on motivation. The combined effect of the different types of rewards will make a deeper and longer-lasting impact on the motivation and commitment of people [10]. 
The result of Purwanenthireen research stated higher the employee rewards lead to higher the employee motivation and lower the employee rewards lead to lower the employee motivation [13]. Expectancy theory explains that motivation will be high when people know what they have to do to get a reward [14].

\section{Method}

This research aims to see the direct effect of reward on motivation. This research is a quantitative study with a survey approach. The study population was all 235 people of Rokan Hulu Regency private junior high school teachers and spread to 20 schools. The total sample of 149 people was obtained using the Slovin formula. Sampling is done by simple random sampling technique. The steps for sampling are:

1. Establishing the school that will be used as the place of research (affordable population)

2. Looking at the number of teachers in each school which is the unit of research analysis

3. Establish a research sample (based on Slovin Formula known to 149 people)

4. Determine the number of samples of each school to represent the characteristics of the population.

The research instrument was a questionnaire. The questionnaire was tested for validity and reliability in 30 teachers outside the study sample. The calculation results are known from 40 items of variable reward instruments, 33 items declared valid. Reliability of the reward instrument has a high category with a score of 0.941 . Meanwhile, of the 38 items of the motivation variable, 32 items were declared valid. The reliability of motivational instruments is also a high category with a score of 0.936 , while the reliability of the reward instrument is also a high category with a score of 0.941 . Data analysis using path analysis. This study proposes one hypothesis, namely there is a direct positive effect of reward on motivation. Dataset can be seen at https://osf.io/y3xkm/ [15].

\section{Result and Discussion}

\subsection{Data Description}

The description of the research data can be seen in the following table :

Table 1. Research Data on Motivation Variables

\begin{tabular}{lc}
\hline Description & Motivation \\
\hline Mean & 126,34 \\
Median & 126,00 \\
Mode & 129,00 \\
Standard Deviation & 5,29 \\
Sample Variance & 27,96 \\
Count & 149 \\
\hline
\end{tabular}


From the table above, it was known that the average score of the motivation variable was 126.34 or $22.15 \%$. While $48.32 \%$ of the samples were in the category above average and $29.53 \%$ of the samples were below the average. Standard deviation was 5.29 ; variance was 27.96; median was 126.00; and the mode was 129.00 .

Table 2. Research Data on Reward Variables

\begin{tabular}{ll}
\hline Description & Reward \\
\hline Mean & 127,65 \\
Median & 128,00 \\
Mode & 132,00 \\
Standard Deviation & 5,88 \\
Sample Variance & 34,62 \\
Count & 149 \\
\hline
\end{tabular}

From the table above, it is known that the average score of the reward variable is 127.65 or $26.17 \%$. While $29.53 \%$ of the samples were in the category above average and $44.29 \%$ of the samples were below the average. Standard deviation was 5.88; variance was 34.62; median was 128.00; and the mode was 132.00 .

\subsection{Normality test}

The results of the Liliefors statistical calculation showed that the normality for motivation for the reward was obtained by Lcal at 0.0371 . Liliefors Ltable critical value for $n=149$ at $\alpha=$ 0.05 is 0.0726 . Based on these results it was known that Lcal $\leq$ Ltable $(0.0371<0.0726)$, so it can be concluded that the distribution of estimated Motivation variable error (Y) on the reward variable $(\mathrm{X})$ came from populations that had a normal distribution.

\subsection{Linearity and Significancy Test}

Based on the results of the calculation data for the preparation of the regression equation model between the Motivation variables and the Reward variable obtained the regression constants $\mathrm{a}=71,115$ and the regression coefficient $\mathrm{b}=0,433$. Thus, the relationship of the simple regression equation model was $\widehat{Y}=71.115+0.433 \mathrm{X}$. Before the regression equation model was analyzed further and used in drawing conclusions, the significancy and linearity of the regression equation test was done first.

Regression equation $\widehat{Y}=71,115+0,433 \mathrm{X}$, for the significancy test obtained Fcount 44.36 bigger than Ftable $(0.01 ; 1: 147) 6.81$ at $\alpha=0.01$. Because Fcount $>$ Ftable, the regression equation was stated to be very significant. For the linearity test obtained Fcount of 1.279 smaller than Ftable (0.05: 26: 121) that was 1.59 at $\alpha=0.05$, This means the Motivation variable regression line (Y) for the Reward variable $(\mathrm{X})$ had a linear pattern .

The form of the relationship between rewards and motivation was shown by the regression equation $\widehat{Y}=71.115+0.433 \mathrm{X}$. The regression equation showed significant cemeaning at 5\% significancy level. This regression equation can be interpreted that the change in one unit of reward score will be followed by a change in motivation score of 0.433 units in the constant 71.115.

The relationship of causality between variables from one endogenous variable was $\mathrm{Y}$ (Motivation) and one exogenous variable was $\mathrm{X}$ (Reward). The results of the analysis showed that the path coefficient of py 1 is 0.481 and tcount $=6.66$, with t table $(0.01: 147)=2.61$, so 
that tcount $>$ ttable $(6.66>2.61)$, reject $\mathrm{H} 0$, means that the variable $\mathrm{X}$ had a positive direct impact on variable $Y$. Thus it was proven, that reward had a positive direct impact on motivation.

The statistical hypothesis tested was a positive direct impact of Reward (X) on Motivation (Y).

Statistically:

$\mathrm{H} 0: \beta y x \leq 0$

H1: $\beta y x>0$

Based on the results of the path analysis of the impact of Reward (X) on Motivation (Y) the $\rho y x$ coefficient path was 0.481 with tcount $=6.66$, while the value of table $=1.98(\alpha=$ $0.05 ; \mathrm{dk}=147)$. Therefore, tcount $>$ ttable, then $\mathrm{H} 0$ was rejected, $\mathrm{H} 1$ was accepted. Thus it can be concluded that the reward has a positive direct effect on motivation.

Based on the results of testing the hypothesis it can be concluded that there was a positive direct impact of reward variable on the motivation variable with a correlation coefficient was 0.481 and a path coefficient was 0.481 . This gave the meaning that reward has a direct positive impact on motivation.

Then it can be concluded that the increasing of rewards for teachers will be able to increase their motivation. The results of this study were supported with Armstrong's opinion which states that the combined effects of different types of rewards will make a deeper and lasting impact on motivation and commitment of people [10].

Teachers who obtain appropriate rewards will be motivated in carrying out their duties. Motivation can be triggered from within and outside ourselves. The reward of the results achieved by the teacher always triggers the teacher to maintain and exceed the achievements that have been achieved. Giving the opportunity for teachers to participate in activities according to their competencies was the highest trigger in this study to realize teacher motivation.

The results of this study were also supported by the research of Ayesha and friends who concluded that, with the advancement in the career path, income level and age intrinsic rewards become the vital factor for the employee motivation [2]. Furthermore, research by Evai Maria which suggested that intrinsic rewards which include task completion, achievement, autonomy and personal growth had a positive and significant influence on employee work motivation [16].

If it was associated with the highest achievement, it was known that the reward in the form of an opportunity to take part in activities related to teacher competencies will be able to improve the understanding of the teacher's work direction, especially relating to teaching students to realize educational goals (being healthy students). In other words to increase teacher motivation can be done by giving rewards.

Based on the results of the study, it is expected that the school principals and related agencies will give more reward to teachers so that their motivation will increase. There should be a government program that teachers receive a minimum salary in accordance with the Regional Minimum Wage (UMR). In addition, there are reward from schools and agencies in the form of teacher quality improvement activities, such as seminars, workshops and the like.

This study also has limitations. This research was only conducted at Private Junior High School, Rokan Hulu Regency therefore it was quite difficult to generalize to wider public and other schools. In addition, further research needs to be done by looking at other variables that influence teacher motivation and different indicators of this study. 


\section{Conclusion}

There was a direct positive impact of reward on motivation. This meant that to increase motivation can be done by increasing the rewards of the private junior high school teachers in the Rokan Hulu Regency.

\section{References}

[1] Mahapatra, Human Resource Management. New Delhi: New Age International Publisher, 2010.

[2] A. B. Safiullah, "Impact of Rewards on Employee Motivation of the Telecommunication Industry of Bangladesh: An Empirical Study," IOSR Journal of Business and Management, vol. 16, p. 9, 2014.

[3] V. Akafo and P. A. Boateng, "Impact of Reward and Recognition on Job Satisfaction and Motivation," European Journal of Business and Management, vol. 7, p. 13, 2015.

[4] M. Y. Khan, M. Rizwan, M. I. Arshad, and M. F. Anwar, "Impact of Employee Motivation on Job Satisfaction With Respect to Corporate Social Responsibility and Rewards," Journal of Public Administration and Governance, vol. 3, p. 17, 2013.

[5] Alpasirin, "Solusi Gaji Guru Komisi, Pangkas Dana Perjalanan Dinas Pegawai," ed. Riau: riauterkini.com, 2018.

[6] J. L. Gibson, J. M. Ivancevich, J. H. D. Jr, and R. Konopaske, Organizations Behavior, Structure, Processes, 14 ed. New York: McGraw Hill, 2012.

[7] S. L. McShane and M. A. V. Glinow, Organizational Behavior emerging knowledge and practice for the real world, 5 ed. New York: McGraw Hill, 2010.

[8] R. L. Daft, Management, 8 ed. USA: Thomson South Western, 2008.

[9] P. D. Mauch, Quality Management Theory and Aplication. USA: CRC Press, 2010.

[10] M. Armstrong, A Handbook of Employee Reward Management Practice, 2 ed. London: Kogan Page, 2007.

[11] L. V. d. Wagen, Human Resource Management for Events managing the event workforce, 1 ed. Burlington USA: Elsevier, 2007.

[12] S. P. Robbins and T. A. Judge, Organizational Behavior 17 ed. England: Pearson, 2013.

[13] P. Pratheepkanth, "Reward System And Its Impact On Employee Motivation In Commercial Bank Of Sri Lanka Plc, In Jaffna District," Global Journal of Management and Business Research, vol. 11, p. 9, 2011.

[14] M. Armstrong, Armstrongs Handbook of Strategic Human Resource Management 5ed. London: Kogan Page, 2011.

[15] Hardianto, "The Effect of Reward Toward Teacher's Motivation of Private Junior High School," Hardianto, Ed., ed: osf.io/y3xkm, 2019.

[16] E. Maria, "Hubungan Penghargaan Intrinsik Terhadap Motivasi Kerja," Jurnal Bisnis dan Ekonomi, vol. 7, p. 9, 2010. 